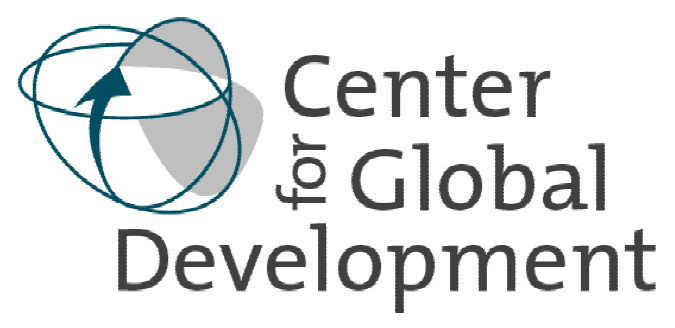

WORKING PAPER NUMBER 12

OCTOBER 2002

\title{
Asymmetric Globalization: Global Markets Require Good Global Politics
}

By Nancy Birdsall

Abstract
The paper sets out two views of the facts about the effects of globalization
on world poverty and inequality. The bottom line: globalization is not the cause,
but neither is it the solution to world poverty and inequality. The paper then
explores why and how the global economy is stacked against the poor, making
globalization asymmetric, at least up to now. It concludes with some ideas about
a new agenda of good global politics, an agenda to shape a future global
economy and society that is less poor and less unequal -- not only because it is
more global and competitive, but also because it is more fair and more politically
representative.





\title{
Asymmetric Globalization: Global Markets Require Good Global Politics
}

Based on remarks, The Carter Center, Development Cooperation Forum Conference on Human Security and the Future of Development Cooperation

\author{
Nancy Birdsall \\ President, Center for Global Development*
}

\section{Center for Global Development \\ Working Paper No. 12}

October 2002

\footnotetext{
* This is a revised version of a speech given at the Carter Center in February, 2002, which was in turn based in part on "Asymmetric Globalization: Outcomes vs. Opportunities," Carnegie Endowment for International Peace Economic Reform Project WP\#7 (September, 2001). Thanks to Tom Carothers of the Carnegie Endowment for International Peace for his comments.
} 
Secure and equitable markets demand political institutions.

.. Markets are the domain of competition; politics, the domain

of collective action.

Luiz Carlos Bresser-Pereira, Getulio Vargas Foundation, Sao Paulo, Brazil

My remarks today are about globalization, its asymmetries between rich and poor, and because of its asymmetries, the need to rethink our global development architecture. I will be talking mostly as an economist this afternoon, but my real theme is that integration of the global economy is outpacing the development of a healthy global polity. ${ }^{1}$ The globalization of markets can and has brought mutual benefits to the rich and poor alike. But it is only through better global politics that the values and rules critical to a secure and just world will be realized, and it is only then that the full benefits of a global market will be available to all.

Put another way, good global politics is critical to the battle against global poverty and unrealized human development, and to a more just and fair as well as a more stable and prosperous global economy.

By globalization I mean the increasing integration of economies and societies, not only in terms of goods and services and financial flows but also of ideas, norms, information and peoples. In popular use, however, the term globalization has come to mean the increasing influence of global market capitalism or what is seen as the increasing reach of corporate and financial interests at the global level.

A debate continues to rage about the merits and demerits of market-led globalization for the poor. On one side of the debate are most mainstream economists, the United Nations, the World Bank and the other international financial institutions, most finance ministers and central bank governors in poor as well as rich countries, and most professional students of development. All of these generally argue that globalization is not the culprit in any increase in world poverty and inequality. It is, after all, the people least touched by globalization, living in rural Africa and South Asia, who are the poorest in the world. On the other side of the debate are most social activists, members of non-profit civil society groups who work on environmental issues, human rights, and relief programs, most of the popular press, and many sensible, well-educated observers. To them, the issue seems self-evident. Globalization may be good for the rich, that is the rich countries and the rich within countries, but it is bad news for the poorest countries, and especially for the poor in those countries.

The furious debate about the merits and demerits of globalization for the poor boils down to a debate about the current distribution of economic and political power in the world, and the

\footnotetext{
${ }^{1}$ This is how Gus Speth put it at the Carter Center Forum.
} 
question of whether the outcome of that distribution of power is just or fair, that is whether it provides for equal opportunities to those who are poor and, in global affairs, relatively powerless. ${ }^{2}$ On this score, I believe it is time for the first group (Ravi Kanbur's Group A economists and finance ministers) to internalize the arguments of the second group (Kanbur's Group B activists and civil society types), and recognize the need for an improved global politics, in which more democratic and legitimate representation of the poor and the disenfranchised in managing the global economy mediates the downside of more integrated and productive global markets.

I begin by setting out two views of the facts about the effects of globalization on world poverty and inequality. The bottom line: globalization is not the cause, but neither is it the solution to world poverty and inequality. Then I explore why and how the global economy is stacked against the poor, making globalization asymmetric, at least up to now. I conclude with some ideas about a new agenda of good global politics, an agenda to shape a future global economy and society that is less poor and less unequal -- not only because it is more global and competitive, but also because it is more fair and more politically representative.

\section{Section 1. Globalization, Poverty and Inequality: Two Views}

For most developing countries, postwar integration began only in the 1980s. Prior to the 1980s, though developing countries participated in some multilateral trade agreements, they did so essentially via special preferences that permitted them to retain relatively high levels of protection of their own markets. In the 1980s, however, and with increasing depth in the 1990s, most developing countries took steps to open and liberalize their markets. Along with reduction and elimination of tariffs and non-tariff barriers came fiscal and monetary reforms, privatization, deregulation, elimination of interest rate ceilings and other changes in the financial sector, and in the 1990s opening of capital markets - a package that came to be known as the Washington Consensus. Liberalization of markets and accompanying, often socially painful structural change, was encouraged and supported by the IMF, the World Bank, and the U.S. Treasury, including with large loans typically conditioned on countries' adopting and implementing agreed policies. The increasing reliance on markets in the developing world, and in the 1990s in the countries of the former Soviet empire, is with good reason seen as part and parcel of the globalization process. And because of the conditioned loans, many of today's protesters see the turn to the market - and thus to global capitalism -- as imposed on the developing countries. (This is so even though, ironically, the international loans generally were disbursed even when agreed conditions were not implemented.)

With the growing influence of markets in the last two decades have come changes in the levels of global inequality and of world poverty. Over the last 100 years, global inequality by

\footnotetext{
${ }^{2}$ Kanbur (2001) notes that the debate may be due to different perspectives between economists and social activists in terms of aggregation and time horizon. That is true. The additional view behind these notes is that their major difference in perspective, however, may well be that the second group is concerned primarily with fairness (as opposed to economic efficiency) and with the apparently disproportionate role of power in the design and implementation of the rules of the global economy.
} 
most measures has been increasing. The ratio of the average income of the richest to the poorest country in the world increased from 9 to 1 at the end of the $19^{\text {th }}$ century to about 30 to 1 in 1960 , to more than 60 to 1 today. ${ }^{3}$ So the average family in the U.S. is 60 times richer than the average family in Ethiopia or Bangladesh (in purchasing power terms). The century-long increase in inequality is the result of a simple reality. Today's rich countries, which were already richer 100 years ago (primarily as a result of the Industrial Revolution), have been blessed with economic growth and have gotten a whole lot richer. Today's poorer countries, mostly in Africa, which were poor to start with, have not grown much if at all.

\section{Global inequality is high, but not necessarily rising}

However, in the last two decades, the picture has changed somewhat. Some countries, including China and its smaller neighbors in East Asia and more recently India, have grown at faster rates than the already rich countries. It is difficult to imagine incomes in those countries ever fully converging to that typical in rich countries. It would take China and India almost a century of growth at faster rates even to reach current U.S. levels. Still, there has been some catching up of income between the advanced industrialized economies and some developing countries - what economists call convergence. ${ }^{4}$

Rapid growth in India and China turns out to be key to the decline of world poverty in the last decade. The percentage of the world's population that is poor (using the World Bank's poverty line of \$1 a day in 1985 dollars) declined between 1987 and 1998 from about 25 percent to 21 percent using World Bank figures, and the absolute number from an estimated 1.2 to 1.1 billion. ${ }^{5}$ The declines in poverty in India and China are key to the overall worldwide decline. Elsewhere in the developing world, including in Africa, Latin America and other parts of Asia, and in the transitional economies of the former Soviet Union, the absolute numbers of poor rose. ${ }^{6}$

Recent studies combine data on differences across countries in average incomes with household data on incomes within countries to produce a "world" distribution of income, in which figuratively speaking, individuals or households around the world are lined up by income in a single unified ranking, and each person (or household) has the same weight in the distribution, independent of whether he or she lives in a small or large country. This is probably the best measure in terms of human welfare of what has been happening in the last couple of decades.

World inequality measured this way is incredibly high - greater than inequality within Brazil and South Africa, the highest inequality countries in the world, where the richest 20 percent of households are about 25 times richer than the poorest 20 percent. And over the last

\footnotetext{
${ }^{3}$ Pritchett (1995).

${ }^{4}$ Cline (2002); Sala-I-Martin (2002); Bhalla (2002), among others.

${ }^{5}$ Bhalla (2002) claims that the decline in India has been underestimated, and that the number of world poor has fallen more, to about 600 million.

${ }^{6}$ Between 1990 and 1998 the number of poor rose by an estimated 59.3 million in Africa; 26.7 million in South Asia; and 10.5 million in Central Asia and Eastern Europe (World Bank 2001).
} 
100 years, it has been increasing, because those differences in historic rates of growth between what have become today's rich and poor countries have dominated this "world" distribution. However in the last 20 years, with the rapid growth of India and China, that trend also has been moderated, and increases in world inequality have slowed. The world distribution as I have described it of course gives much greater weight to these high population countries. As a result, if we compare not changes in average incomes between the richest and poorest countries, but changes in average incomes between the initially 20 percent richest and 20 percent poorest individuals in the world (say about two decades ago), we find that world inequality, though incredibly high, has been leveling off in this recent era of "globalization".

Changes in inequality within countries have not made much difference to this overall story. Income inequality has been increasing steadily in the United States since the early 1970s, though the increase did level off finally in the last couple of years. In the last two decades, income inequality increased in China, where phenomenal income growth has been heavily concentrated in urban areas; in most countries of Eastern Europe and the former Soviet Union, where growth has been minimal and the current poor are worse off than they were before the fall of Communism; and in Mexico, Panama and Peru in Latin America, where it rose during the low-growth years of the 1980s and failed to decline with the return to modest growth in the 1990s. On the other hand, it would be an exaggeration to say that rising inequality within countries has been the norm, or to associate it specifically with increasing global integration. In most countries, income inequality has simply not changed, and in a few, including Japan, Canada, and Italy among industrialized countries, and Bangladesh, Ghana and the Philippines, it appears to have declined.

So at the world level, it is fair to say that poverty is declining and inequality is not increasing, even though that is not the case within many countries. Today's global inequality is mostly a matter of differences between rich and poor countries in past rates of growth. That brings us back to the main argument of globalization's proponents. It is countries that have successfully entered the global market and participated in globalization that have grown most. In the past, that included Japan, beginning in the Meiji era between 1868 and 1912; the poorer countries of Western Europe during the $19^{\text {th }}$ century and then again during the post World War II period of European integration; and among the developing world in the postwar era, the socalled miracle economies of East Asia in the three decades before the 1998 financial crisis. More recently, it has included China, India, and in addition Bangladesh, Brazil, Malaysia, Mexico, Mozambique, the Philippines, Thailand, Uganda and Vietnam. ${ }^{8}$ Poverty remains highest in the countries (and regions) and for peoples that are marginal to global markets,

\footnotetext{
${ }^{7}$ See Sala-I-Martin (2002) and Cline (2002b) for this result using alternative measures of inequality. These studies all compare incomes across countries in purchasing power parity terms. Milanovic (2002) reports a slight increase in the world distribution between 1988 and 1993, but the difference he reports is not statistically robust. Wade (2001) sets out technical counterarguments to the mainstream view that world inequality has leveled off. He notes that by most definitions and measures, except for the "world distribution" in PPP terms, inequality has increased.

${ }^{8}$ Dollar and Kraay (2001). Even though income inequality within some of these countries failed to decline or even increased (China especially), their average growth has brought their populations as a whole closer to the income of the rich countries, reducing world inequality.
} 
including many in Africa, some in South Asia, and among people, the rural populations of China, India, and Latin America. To the extent that globalization has "caused" increasing inequality, it is not because some have benefited a lot - a good thing - but because others have been left out of the process altogether.

\section{Globalization is not the solution}

Globalization is not the cause but neither is it the solution to continuing miserable poverty and haunting inequality at the global level. Consider first the plight of a large group of the poorest countries, including many in Africa. Highly dependent on primary commodity and natural resource exports in the early 1980s, they have been "open" for at least two decades, if openness is measured by their ratio of imports and exports to GDP. But unable to diversify into manufacturing (despite reducing their own import tariffs) they have been victims of the decline in the relative world prices of their commodity exports, and have, literally, been left behind. ${ }^{9}$ These countries have not been xenophobic or in any way closed to the global economy. But despite rising exports, tariff reductions, and economic and structural reforms including greater fiscal and monetary discipline and the divestiture of unproductive state enterprises, they have been unable to increase their export income, have failed to attract foreign investment, and have grown little if at all. ${ }^{10}$

Many of these countries in sub-Saharan Africa, as well as Haiti, Nepal, and Nicaragua, seem trapped in a vicious circle of low or unstable export revenue, weak and sometimes predatory government, inability to cope with terrible disease burdens (the HIV/AIDS pandemic being only one recent and highly visible example), and failure to deliver the basic education and other services to their children that are critical to sustainable growth. Their governments have made, from time to time, fragile efforts to end corruption, to undertake economic reforms, and, more to the point, to enter global markets. But, caught in one variety or another of a poverty trap, "globalization" has not worked for them. For these countries, success in global markets might be a future outcome of success with growth and development itself, but it does not look like a good bet as a key input.

For the better-off emerging market economies globalization has failed to work on another dimension. For them global trade has been generally a boon, but global financial markets pretty much a bust. In the last decade, Mexico, Korea, Thailand, Indonesia, Russia, Brazil, Ecuador, Turkey and this year Argentina were all hit by financial crises triggered or made worse by their exposure to global financial markets. For these countries the benefits of global financial markets

\footnotetext{
${ }^{9}$ Birdsall and Hamoudi (2002) argue that the use of the trade/GDP ratio to represent policy openness is misleading as many of Dollar and Kraay's (2001) “non-globalizers" are commodity-dependent exporters with limited import protection.

10 The problems of these countries have often been compounded by the concentrations of wealth and the internal conflicts over control of their natural resources to which they seem so prone. Of course, there are many possible reasons for stalled growth; in many commodity-dependent countries: poor governance, civil conflicts, high disease burdens and bad geography.
} 
have been heavily offset by their increased risks. Because their local financial markets are less resilient, and local and foreign creditors more wary, they are much more vulnerable than their industrial country counterparts to the panicked withdrawal of capital typical of bank runs. Particularly troubling is the growing evidence that the financial instability associated with open capital markets is especially costly for the working poor and the emerging middle class, and tends to exacerbate inequality within countries. ${ }^{11}$ In Turkey, Argentina and Mexico, with repeated bouts of inflation and currency devaluations in the last two decades, the ability of those with more financial assets to move them abroad, often simultaneously acquiring bank and corporate debt that is then socialized and paid by taxpayers, has been disequalizing - and certainly appears unfair. In parts of Asia and in much of Latin America, inequality increased during the boom years of high capital inflows in the mid-1990s as portfolio inflows and high bank lending fueled demand for assets such as land and stocks, which were beneficial to the rich.

In both regions the poor and working class gained the least during the pre-crisis boom, and then lost the most, certainly relative to their most basic needs, in the post-crisis bust. The high interest rates to which the affected countries resorted to stabilize their currencies also had a redistributive effect, hurting most small capital-starved enterprises and their low-wage employees. The bank bailouts that often follow financial crises create public debt that is seldom equally shared; public debt implies a transfer from taxpayers to rentiers. China and India have kept their capital markets relatively closed, and survived relatively well the financial crises of the late 1990s compared to Mexico, Argentina and Thailand. Success in trade is good for growth and that benefits the poor, but rapid and near-complete opening of capital markets, heavily pushed by the IMF and the U.S. Treasury throughout the $1990 \mathrm{~s}$, is not so simple in its effects. ${ }^{12}$ It is no wonder that social activists are suspicious of corporate and financial influence in global markets.

A third problem with "globalization" has been the link between market reforms and the potential for new and costly rounds of corruption. Privatization and liberalization of financial markets in the absence of adequate regulatory institutions and banking standards and supervision invite corruption; Russia is only the most visible example. Open capital markets make it easier for corrupt leaders to burden their own taxpayers with official and private debt while transferring resources to their own foreign bank accounts. Unregulated markets make money laundering and tax evasion easier, and raise the costs asymmetrically for poor countries to defend their own tax systems. Globalization and global capital markets are not the underlying cause of all these problems, but like an occasion of sin they increase the likelihood that human failings will corrupt the system, usually at a cost to the poor and powerless.

\section{Section 2: Unequal Opportunities: The Global Economy is Stacked Against the Poor}

Not all the suspicions of the activists are necessarily warranted. But they are right in one important respect. Globalization is not necessarily the solution to high levels of poverty and

\footnotetext{
${ }^{11}$ Birdsall (2002).

${ }^{12}$ Among others Stiglitz (1999), and Easterly, Islam and Stiglitz (2000) emphasize this point, for developing countries in general and for the poor within them.
} 
inequality; indeed the relatively benign outcomes of globalization up to now belie unfair opportunities in an unfair global economy. Let me suggest three ways in which the global economy sustains or worsens unequal opportunities.

- The market works; in the global market game, those without the right training and equipment inevitably lose;

- the market fails; in the global economy, negative externalities raise new costs for the vulnerable and compound the risks faced by the already weak and disadvantaged;

- in the global game, economic power matters more than ever across countries; it is natural that the rich and powerful can influence the design and implementation of global rules to their own advantage.

\section{The market works}

Globalization is shorthand for global capitalism and the extension of global markets. Markets that are bigger and deeper reward more efficiently those who already have productive assets: financial assets, land, physical assets, and perhaps most crucial in the technologically driven global economy, human capital. This is true not just across people but across countries too. The economic return to healthy and stable country institutions is huge. Countries that are already ahead - with stable political systems, secure property rights, adequate banking supervision, reasonable public services, and so on - are better able to cope with market-driven changes in world prices. I mentioned above that many countries heavily dependent on commodity exports seem caught in a poverty trap. But that has not been the case for countries that entered the global economy with the "asset" of strong political and social institutions (e.g. Australia, Chile, Norway). Their pre-existing institutional assets explain much of why 80 percent of all foreign investment occurs among the industrialized countries while just 0.1 percent of all U.S. foreign investment went to sub-Saharan Africa last year. ${ }^{13}$

In short, countries caught in an "institutional poverty trap" will not necessarily benefit from a healthy global market. Of course there is nothing necessarily permanent about a poverty trap. Like poor and uneducated people, with the right rules and some help from friends, countries can escape welfare dependency. But more on that below.

At the individual level, the best example of how healthy markets can generate unequal opportunities is the rising returns throughout the world to higher education. The effect of having a university education compared to secondary education or less has been increasing for years everywhere. This is true despite the fact that more and more people are going to university. In the global economy, with the information and communications revolution, the supply of university-educated people has not been keeping up with ever-increasing demand. In the United

\footnotetext{
${ }^{13}$ UNCTAD (2001).
} 
States the highly educated have enjoyed healthy earnings gains for three decades, while those with high school education or less have suffered absolute wage losses. Similarly in Latin America, between 1991 and 1995, the period of intense liberalization, the wage gap between the skilled and unskilled increased for six of seven countries for which reliable wage data are available. In Eastern Europe, with the fall of Communism, the wage difference between those with and without post-secondary education has widened considerably. ${ }^{14}$ Just about everywhere in the world (Cuba, China, Kerala state in India, all socialist entities being exceptions) education reinforces initial advantages instead of compensating for initial handicaps.

Rising wage gaps in open and competitive markets should not surprise or alarm us; they may be a short-term price worth paying for higher long-run sustainable growth. They create the right incentives for more people to acquire more education, in principle eventually reducing inequality. The same can be said for the development of institutions at the country level. Many poor countries have responded to global opportunities by strengthening the rule of law, building and strengthening democratic processes, and investing in public health and education. But just as poor families need resources as well as incentives to educate their children, so poor countries need resources as well as reforms to build their institutions.

The global market for skilled and talented people is another example of how markets can hurt the already weak. In today's global economy the highly skilled are highly mobile. Indian engineers can quadruple their earnings by moving from Kerala to Silicon Valley, and Indian Ph.D. biochemists from Delhi to Atlanta or Cambridge. For the individuals concerned, this is a good thing, and eventually this brain drain can generate offsetting remittances and return investments if the institutional and policy setting in India and other poor countries improves. ${ }^{15}$ In the short run, however, it makes the task of poorer countries, trying to build those institutions and improve those policies, tougher. The annual loss to India of its brain drain to the U.S. is estimated at $\$ 2$ billion, about equal to all the foreign aid it receives. ${ }^{16}$ The farmers and workers whose taxes finance education in poor countries are subsidizing the citizens of the rich countries -- whose tax revenues are boosted by the immigrants' contributions (and whose cultures by the way are also greatly enriched).

The efficiency gains and increased potential for growth of a global market economy are not to be disdained. But in modern market economies, there is a well-defined social contract that tempers the excess inequalities of income and opportunity that efficient markets easily generate. The social contract may not be perfect, but it exists at the national level. Progressive tax systems provide for some redistribution, with the state financing at least minimal educational opportunities for all and some social and old age insurance. At the global level, there is no analogue. Statements of social and economic rights in the United Nations, and relatively minor transfers of financial and technical resources from rich to poor countries are as close as we have come to managing a global social contract. Ironically, one problem with the World Bank, a

\footnotetext{
${ }^{14}$ For more on the United States see Levy (1999) or Cline (trade and inequality); on Latin America see Duryea and Szekely (1998); on Eastern Europe see Terrell (2001); on Mexico author's calculations.

${ }^{15}$ Kapur (forthcoming).

${ }^{16}$ UNDP (2001) and UNDP India (1998).
} 
lightning rod for anti-globalization protests, may not be that it is too powerful, but that it is too weak to manage a global social contract.

\section{The market fails}

Markets fail in many domains. Global markets compound the risks and costs of market failures for the weak. What is true at the local level, where local polluters do not internalize the costs of their pollution, obtains at the global level, and often in spades. The rich countries that have historically emitted the highest per capita greenhouse gas emissions have imposed costs on the poor. As the biggest polluter in per capita terms, the United States is imposing costs not only on its own future citizens, but also on the children and grandchildren of the world's poor, who are much less likely to have the resources to protect themselves from the effects.

Financial contagion across countries, affecting even those emerging market economies with relatively sound domestic policies, is another example of how market failures can affect the already vulnerable asymmetrically. The problem the emerging market economies of Latin America and East Asia face in global financial markets has not only brought instability and reduced growth; it has affected their capacity to develop and sustain the institutions and programs they need to protect their own poor. With global market players doubting the commitment of non-industrialized countries to fiscal rectitude at the time of any shock, countries are forced to resort to tight fiscal and monetary policy to reestablish market confidence, just when in the face of recession they would ideally implement macroeconomic measures to stimulate their economies. The (procyclical) austerity policies that the global capital market demands of emerging market are the opposite of what the industrial economies implement - such as reduced interest rates, unemployment insurance, increased availability of food stamps and public works employment - fundamental ingredients of a modern social contract. We know that the effects of unemployment and bankruptcy can be permanent for the poor; in Mexico, increases in child labor that reduced school enrollment during the 1995 crisis were not reversed, implying some children did not return to school when growth resumed. ${ }^{17}$

The risks of global warming and the problems of global financial contagion are only two examples of market failures that entail asymmetric costs and risks for poor countries and poor people. The same can be said of contagious disease that crosses borders, of transnational crime, and of potentially beneficial but risky new technologies such as genetically modified foods. Similarly, poor countries that protect global resources such as tropical forests and biological diversity are paying the full costs but are unable to capture the full benefits of these global goods. Within countries, governments temper market failures through regulations, taxes and subsidies, and fines; and they share the benefits of such public goods as public security, military defense, management of natural disasters and public health through their tax and expenditure decisions. Ideally the latter are made in a democratic system with fair and legitimate representation of all people, independent of their wealth. In nations, such political systems

\footnotetext{
${ }^{17}$ Szekely (2001).
} 
seldom work perfectly (as the proponents of campaign finance reform in the U.S. would argue). In the global community, a comparable political system just barely exists.

\section{Economic power influences global rules and their implementation}

Trade is the best and thus the worst and most costly example for the poor. In general, political constraints in rich and powerful countries dominate the design of global rules. The resulting protection of agriculture and textiles in the U.S. and Europe locks many of the world's poorest countries out of potential markets. Because these are the sectors that could generate jobs for the unskilled, rich country protection, through tariffs and subsidies, hurts most the poor. ${ }^{18}$ The recent initiative of the European Union to eliminate all barriers to imports from the world's 49 poorest countries, and the African Growth and Opportunity Act in the U.S. are steps in the right direction. But since the countries that can benefit make up only a minuscule proportion of all world production, they represent very small steps indeed. And even those modest initiatives were watered down considerably by domestic political pressures, and include complicated rules that create uncertainty and limit big increases in poor country exports.

Political constraints also affect the way already agreed trade rules are implemented. The process of complicated negotiations and dispute resolution puts poor and small countries with limited resources at a disadvantage. The use of anti-dumping actions by U.S. producers, even when they are unlikely to win a dispute on its merits, creates onerous legal and other costs to current producers in developing countries, and chills new job-creating investment in sensitive sectors. About one-half of anti-dumping actions are initiated against developing country producers, who take up 8 percent of all exports. ${ }^{19}$ Even the Bush Administration, with the right rhetoric on free trade, could not resist the pressure of the U.S. steel industry to invoke antidumping legislation.

International migration is governed by rules that are also stacked against the developing countries, and in particular against the poor and unskilled in those countries. Permanent migration is small relative to the past because higher-income countries restrict immigration. In the last 25 years, only 2 percent of the world's people have changed their permanent country residence, compared to 10 percent in the 25 years before WWI. ${ }^{20}$ Yet more movement would reduce world inequality considerably, as did the tremendous movements of Europeans to the Americas in the $19^{\text {th }}$ century. ${ }^{21}$ An auto mechanic from Ghana can at least quintuple his income, just by moving from Ghana to Italy; as can a Nicaraguan agricultural worker, by moving to Arizona. During the recent boom in the information technology sector, the United States established a special program to allow highly skilled workers to enter with temporary visas - a good thing, no doubt, for the individual beneficiaries, but also an implicit tax on the working taxpayers in poorer countries who helped finance the education of those emigrants, and another example of the capacity of the already rich to exploit their power.

\footnotetext{
${ }^{18}$ World Bank (2001).

${ }^{19}$ Author's calculations based on World Trade Analyzer and Finger and Schuknecht (1999).

${ }^{20}$ Dollar and Kraay (2002).

${ }^{21}$ O'Rourke and Williamson (1999).
} 
What about intellectual property rights? Because knowledge is not an excludable good, it makes sense to compensate for the resulting market failure through intellectual property rights. At the global level, those rights are now regulated by the WTO, under what is called the TRIPS, or trade-related intellectual property rights agreement. Intellectual property rights ideally balance society's gains from incentives for invention with the benefits of access to resulting products. But it is highly debatable whether the current international regime has achieved an appropriate balance in the poorest developing countries, where the minimum 20-year patent period under TRIPS implies higher costs for many products - the most notorious example being now in the area of AIDS anti-virals with little likelihood of local creation of new products.

In fact the WTO rules allow countries to issue compulsory licenses for the production and importation of patented products, under certain circumstances. The U.S. issues compulsory licenses to mitigate the monopoly power, and Canada before signing NAFTA regularly issued compulsory licenses for the domestic production of patented pharmaceuticals. But implementation of this aspect of TRIPS has been affected by the imbalance of power. U.S. pharmaceutical firms have systematically pressured the United States Trade Representative to threaten extra-WTO sanctions against countries threatening to use compulsory licensing. Under tremendous pressure from civil society groups in the case of AIDS drugs, the U.S. has desisted from bringing formal actions against South Africa and more recently Brazil. But Thailand is still under pressure, and for other less visible health problems business as usual puts the weak at a disadvantage against the strong.

Economic power also affects the rules and the conduct of those rules by the international institutions. The International Monetary Fund is the world's institution meant to help countries manage macroeconomic imbalances and minimize the risks of financial shocks. But in the 1990s, the IMF was too enthusiastic about developing countries' opening their capital accounts. This is only one example where the IMF and the World Bank have been insufficiently humble in their recipes and probably all too heavily influenced by their richer members. Even if the policies supported have made sense - and I believe for the most part they have - the reality is that those who advocate them have no real accountability to the people in developing countries most affected by them. For one thing, developing countries are poorly represented, at least in the voting structure of these institutions.

\section{Conclusion: A New Agenda of Good Global Politics}

That poverty is declining worldwide and inequality after a century is leveling off is not a sign that all is well in our new globalized economy. Proponents of market-led globalization need to recognize that the global economy, even if it is not causing more poverty and inequality, is not addressing those global problems either, and is ridden with asymmetries that add up to unequal opportunities. Social activists need to insist on the reform not the dismantling of the limited institutions for managing globalizations downside. Both groups need to join forces in pushing a new global agenda, aiming for a new global politics to accompany the global economy. They need to focus on the good political arts - of arguing, persuading, compromising and cooperating 
in collective action for the commonweal.

\section{A global social contract}

Statements of social and economic rights in the United Nations, and relatively minor transfers of financial and technical resources from rich to poor countries are as close as we have come to anything like a global social contract. Anyone arriving from another planet into our highly unequal global economy would have to conclude that rich countries have no interest at all in doing anything much to help the poor in poor countries - surprisingly given what could be their enlightened self-interest in a more secure and prosperous global economy. The logic of a global social contract is clear, but it cannot be constructed out of nothing. As is the case within countries, a social contract involves some transfers - for investments in the human capital and the local institutions that can ensure equal opportunities for the poor.

The business of foreign aid is more effective and sensible than in the Cold War era, but more can be done to make it competitive, effective, and better channeled to those countries with the greatest need and reasonable capacity to use resources well. The program of official debt relief is an admission that past aid to the poorest countries has not worked. It should also be a first step in a larger reinvention of the foreign aid business - away from tied aid, multiple and onerous standards of different donors, and conditionality that doesn't work, and toward a more generous but more disciplined system. ${ }^{22}$ At the same time, the need to do better should not be an excuse for the rich countries' minimal spending on foreign aid. With many poor countries consolidating reforms, and with Cold War misuse of aid behind us, the ability to spend resources well now far exceeds the available amounts. Domestic social contracts, in the form of public transfers for investing in education, health, housing and so forth, and for social safety net programs such as unemployment insurance and disability and taxpayers financed welfare and pensions programs, usually amount to more than 10 percent of GDP. Foreign aid for a global social contract is below 0.5 percent of rich countries' combined GDPs.

Most important, the global and regional institutions we have that are the world's most obvious mechanisms for managing a global social contract need to be reformed, not dismantled. It is ironic that the World Bank and the IMF have been the lightning rod for anti-globalization protests. It may be not that they are too powerful but too limited in their resources and insufficiently effective to manage a global contract that would bring equal education, health and other opportunities to the poor in poor countries. Making them more representative and more accountable to those most affected by their programs, and thus more effective, has to be on the agenda of better global politics.

\section{Addressing global market failures}

The returns to spending on global public goods that benefit the poor have been extraordinarily high. This is the case of tropical agricultural research, public health research and

\footnotetext{
${ }^{22}$ Birdsall and Williamson (2002); Easterly (2002).
} 
disease control, and the limited global efforts to protect regional and global environmental resources. These global programs need to be financed by something that mimics taxes within national economies. The IMF is now proposing a new approach to sovereign bankruptcy that might make the costs of financial crises less great for poor countries and poor people. Global agreements on bankruptcy procedures, on reducing greenhouse gas emissions, on protecting biodiversity and marine resources, on funding food safety and monitoring public health are all development programs in one form or another - because they reduce the risks and costs of global spillovers and enhance their potential benefits for the poor.

\section{Just global rules and full and fair implementation}

Reducing protection in rich country markets belongs on the agenda of all those fighting for global justice and the elimination of world poverty. Many developing countries are at an unfair disadvantage in global trade and other negotiations, and they need transfers from rich countries simply to effectively participate. This is especially the case for smaller and poorer countries.

Rich counties should make increasing efforts to open their doors to unskilled and not just skilled immigrants, allocating resources at home to ease the adjustment of native workers through job training. The rules governing international migration are notably illiberal. Even within political constraints, much more could be done by the rich countries in their own interests to make immigration regimes more sensible and more consistent with their overall policies in support of developing countries a part of their overall development policy. Sharing of tax receipts of skilled immigrants across sending and receiving countries is one example. Another is the effort to reduce the transaction costs of remittances. These could help offset the perverse effects of the brain drain on poor countries.

It is time to revisit the delicate problem of balancing public health needs with the benefits of an international regime of intellectual property rights. There is plenty of scope to do this within current WTO rules.

In general the developing countries should be more fully and fairly represented in international institutions; this is especially the case in the international financial institutions, whose policies and programs are so central to their development prospects.

Those concerned with global justice - whether Kanbur's Group A economists and finance ministers or Group B activists - face a daunting problem of global collective action. They need to make a common agenda, for a global social contract that would make meaningful investments in economic opportunities for the poor possible; for global rules and regimes in trade, foreign investment, property rights and migration that are more fair; and for global institutions that are more representative and accountable to the poor as well as the rich. In practical terms that means working together in the short run to build a more level playing field in 
global governance. It means reforming rather than undermining the existing global institutions, so they can manage the downside of globalization, reduce its asymmetry, and provide for a more equal world because it is more just. The two groups need to come together in insisting that a new global development architecture be based on good global politics and not just expanded global markets. 


\section{References:}

Bhalla, Surjit S. (2002). "Imagine There is No Country: Globalization and its Consequences for Poverty, Inequality and Growth" (processed).

See: http://www.oxusresearch.com/downloads/imagine2002.PDF

Birdsall, Nancy. (2002). "A Stormy Day on an Open Field: Asymmetry and Convergence in the Global Economy." Paper presented at "Globalisation, Living standards and Inequality: Recent progress and continuing challenges," a conference hosted by the Group of 20, Australian Federal Reserve Bank and Australian Treasury. Sydney, Australia.

See: http://www.cgdev.org

Birdsall, Nancy and Amar Hamoudi. (2002). "Commodity Dependence, Trade, and Growth: When "Openness" is Not Enough." Center for Global Development, Working Paper No. 7. See: http://www.cgdev.org/wp/cgd_wp007.pdf

Birdsall, Nancy and John Williamson with Brian Deese. (2002). Delivering on Debt Relief: From IMF Gold to a New Development Architecture. Washington, D.C.: Center for Global Development and Institute for International Economics.

Cline, William. (2002). "Financial Crises and Poverty in Emerging Market Economies" Center for Global Development, Working Paper No. 8.

See: http://www.cgdev.org/wp/cgd_wp008.pdf

(2002b). "Convergence versus Divergence in International Income Levels" in Trade Policy and Global Poverty. (Draft)

Diwan, Ishac. (2002). "Debt as Sweat: Labor, financial crises, and the globalization of capital" Washington, D.C.: World Bank.

See: http://www.worldbank.org/wbi/B-SPAN/docs/diwan.pdf

Dollar, David and Art Kraay. (2001, June). "Trade, Growth, and Poverty." World Bank, Macroeconomics and Growth Group Working Paper, No. 2615.

See: http://www.worldbank.org/research/growth/pdfiles/Trade5.pdf

Dollar, David and Art Kraay (2002, January/February) “Spreading the Wealth" Foreign Affairs pg

Duryea, Suzzane and Miguel Szekely. (1998) "Labor Markets in Latin America: A supply side story" Paper prepared for the annual meeting of the Inter-American Development Bank, Cartagena.

Easterly, William. (2002). "The Cartel of Good Intentions: Markets vs. bureaucracy in foreign aid" Center for Global Development, Working Paper No. 4. 
See: http://www.cgdev.org/wp/cgd_wp004_rev.pdf

Easterly, William, Roumeen Islam and Joseph Stiglitz. (2000, April). "Shaken and Stirred: Explaining Growth Volatility," Proceeding of Annual World Bank Conference on Development Economics. Washington D.C.: World Bank pp 191-211.

See: http://www.worldbank.org/research/growth/growth\%20volatility\%20jan\%202000.html

Finger, J. Michael and Ludger Schuknecht "Market Access Advances and Retreats: The Uruguay Round and Beyond" World Bank, Working Paper.

See: http://econ.worldbank.org/docs/959.pdf

Kanbur, Ravi. (2001). "Economic Policy, Distribution and Poverty: The Nature of Disagreements." World Development. 29 (6) pp. 1083-1094.

Kapur, Davesh. (Forthcoming). Global War: The Global Competition for Talent Washington D.C.: Center for Global Development.

Levy, Frank. (1999) The New Dollars and Dreams: American Incomes and Economic Change. New York: Russell Sage Foundation

Milanovic, Branko. (2002). "True World Income Distribution, 1988 and 1993: First Calculations Based on Household Surveys Alone.” World Bank, Policy Research Working Paper 2244. See: http://www.worldbank.org/poverty/inequal/abstracts/recent.htm

Pritchett, Lant (1995). “Divergence Big Time” World Bank, Policy Research Working Paper 1522.

O'Rourke, Kevin H. and Williamson, Jeffrey G. (1999). Globalization and History-Evolution of a Nineteenth-Century Atlantic Economy, Cambridge, Mass: The MIT Press.

Sala-i-Martin, Xavier (2002). “The World Distribution of Income (estimated from Individual Country Distributions)" National Bureau of Economic Research, Working Paper 8933.

Inter-American Development Bank. (1999). Facing up to Inequality in Latin America 1998-1999 Report on the Economic and Social Progress in Latin America. New York: Oxford University Press.

Stiglitz, Joseph. (1999). "Foreward" to Global Economic Prospects in Developing Countries: Beyond Financial Crisis. Washington D.C.: International Bank for Reconstruction and Development/The World Bank.

See: http://www.worldbank.org/prospects/gep98-99/foreword.htm

Terrell, Katherine. (2000). "Worker Mobility and Transition to a Market Economy: Winners and 
Losers." In Nancy Birdsall and Carol Graham (Ed.) New Markets, New Opportunities: Economic and Social Mobility in a Changing World. Washington D.C.: The Brookings Institution.

United Nations Conference on Trade and Development. (2001).World Investment Report 2001. New York: United Nations

United Nations Development Programme. (2001). Human Development Report 2001: Making New Technologies Work for Human Development. New York: Oxford University Press.

United Nations System India. (1998). "Annual Report of the Resident Coordinator for India." Delhi, India: United Nations. See: http://www.un.org.in/rc/rc98/overview.htm

Wade, Robert (April 26, 2001). "Winners and Losers" The Economist.

World Bank (2001). World Development Report: Attacking Poverty. New York: Oxford University Press

(2001b). Global Development Finance: Building Coalitions for Effective Development Einance. Washington, D.C.: World Bank. 


\section{Center for Global DeVelopment Working PAPERS}

\section{AVAILABLE AT WWW.CGDEV.ORG}

No. 1, January 2002

No. 2, January 2002

No. 3, February 2002

No. 4, March 2002

No. 5, April 2002

No. 6, May 2002

No. 7, May 2002

No. 8, June 2002

No. 9, August 2002

No. 10, September 2002

No. 11, October 2002
Inequality Does Cause Underdevelopment: New Evidence. William Easterly

HIV/AIDS and the Accumulation and Utilization of Human Capital in Africa Amar Hamoudi and Nancy Birdsall

External Advisors and Privatization in Transition Economies John Nellis

The Cartel of Good Intentions: Bureaucracy versus Markets in Foreign Aid William Easterly

Intellectual Property and the Availability of Pharmaceuticals in Developing Countries Jean O. Lanjouw

Winners and Losers: Assessing the distributional impacts of privatization. John Nellis and Nancy Birdsall

Commodity Dependence, Trade, and Growth: When 'Openness' is Not Enough. Nancy Birdsall and Amar Hamoudi.

Financial Crises and Poverty in Emerging Market Economies.

William Cline

An Identity Crisis? Testing IMF Financial Programming, William Easterly

Solutions when the Solution is the Problem: Arraying the Disarray in Development, Lant Pritchett and Michael Woolcock

What did structural adjustment adjust? The association of policies and growth with repeated IMF and World Bank adjustment loans.

William Easterly 